\title{
Stevens-Johnson syndrome in children receiving phenobarbital therapy and cranial radiotherapy
}

\author{
Antonio Ruggiero - Paola Sabrina Buonuomo • \\ Palma Maurizi · Maria Giuseppina Cefalo • \\ Mirta Corsello · Riccardo Riccardi
}

Published online: 26 January 2008

(C) Springer Science+Business Media, LLC. 2008

Erratum to: J Neurooncol (2007) 85:213-215

DOI 10.1007/s11060-007-9399-y

The fourth author's name was misrepresented in the original publication.

The online version of the original article can be found under doi:10.1007/s11060-007-9399-y.

\footnotetext{
A. Ruggiero - P. Maurizi - M. G. Cefalo - M. Corsello · R. Riccardi

Department of Paediatrics, Pediatric Oncology, Università Cattolica del Sacro Cuore, Policlinico “A. Gemelli”, Rome,

Italy

P. S. Buonuomo $(\bowtie)$

Department of Pediatric Medicine, Ospedale Pediatrico,

"Bambino Gesù' IRCCS, Rome, Italy

e-mail: savabi@libero.it
} 